\title{
Get to know Crowdfunding
}

Wina illirian sevi rahmadanti

Email : $\underline{\text { illiriansevi@gmail.com }}$

Crowdfunding adalah sejenis crowdsourcing dengan memungkinkan pendukung online untuk terlibat proyek sosial untuk berkontribusi pada sumber daya dalam mengatasi masalah sosial, yang serupa logika sebagai crowdsourcing dalam proyek humaniora (Terras, 2015). Crowdfunding, sebagai jenis crowdorganising, termasuk "transaksi spot, hubungan jangka pendek, harga berbasis permintaan, permintaan yang beragam, dan reputasi yang dibangun melalui mekanisme umpan balik " "Humaniora digital" adalah area di mana ilmu komputer dan humaniora bersinggungan.. Munculnya teknologi dan sumber daya digital dalam pertanyaan humaniora menolak tantangan proyek agar berkelanjutan (Zhang et al., 2015). bertujuan untuk memahami bagaimana wirausaha sosial mengadopsi crowdfunding dalam bentuk digital humaniora dengan menyelidiki penyimpangan misi, berbagi risiko dan praktik sumber daya manusia Kami menggunakan metode kualitatif untuk mengevaluasi lima usaha sosial, yang mempraktikkan jenis yang berbeda aktivitas crowdfunding di Indonesia.

Platform crowdfunding adalah contoh terbaik tentang bagaimana humaniora digital termasuk proyek khusus yang menggunakan pendekatan humaniora untuk membangun sumber daya digital, yang menimbulkan minat luas pada humaniora itu sendiri (Rockwell, 2013). Humaniora digital tidak hanya mewakili kumpulan nilai divergensi dengan tujuan bersama untuk memajukan pengetahuan, membina inovasi dan melayani publik tetapi juga bertujuan untuk konflik, yang mengungkapkan ideologi yang berbeda (Spiro, 2012). Karenanya, keseimbangan antara teknologi dan penyelidikan humanistik menjadi sentral untuk gelar humaniora digital (Hergenrader, 2017).

Crowdfunding telah muncul sebagai metode yang efektif untuk mengumpulkan dana bagi penciptaan dan kesuksesan usaha baru. Meskipun demikian, pengetahuan kami terbatas tentang motivasi untuk pemilihan dan dukungan finansial crowdfunding, khususnya untuk donor dalam crowdfunding amal yang tidak mendapatkan imbalan uang atas kontribusinya. Temuan tersebut mengungkapkan kombinasi motivasi 
intrinsik dan ekstrinsik yang mengarahkan perilaku pendanaan para donor. penelitian ini mengeksplorasi kontribusi untuk memenuhi upaya kolektif, efektivitas yang dirasakan dan sedikit risiko crowdfunding sebagai motivasi sosial intrinsik untuk sumbangan ke proyek amal crowdfunding. berkontribusi dalam memecahkan masalah sosial, meningkatkan kesadaran dan pengetahuan masyarakat tentang masalah tersebut, serta menciptakan mobilitas dan tindakan dalam masyarakat dan masyarakat untuk menyelesaikan masalah sebagai motivasi ekstrinsik sosial yang mengatur donor untuk secara finansial mendukung crowdfunding amal. Temuan ini dibahas dalam kaitannya dengan implikasinya terhadap pengembangan teori, praktik, dan penelitian crowdfunding. Jika dibandingkan dengan artikel milik pak Hery Pratono crowdfunding selalu memiliki humaniora yang selalu dipakai untuk hal sosial, atau layanan sosial, crowdfunding telah menjadi respon yang unik, kampanye aktif diambil dari situs web crowdfunding populer menggunakan istilah di pencarian. Seperti contoh dalam artikel 'menjelajahi kampanye crowdfunding untuk layanan aborsi Keberhasilan kampanye tidak berbeda dengan kebijakan aborsi negara bagian, tetapi kampanye yang ditulis dengan sudut pandang orang ketiga atau menggambarkan diagnosis ibu / janin menghasilkan lebih banyak uang secara signifikan. Kesimpulan Meskipun individu menggunakan crowdfunding untuk mendanai layanan aborsi, tingkat keberhasilannya rendah.

\section{DAFTAR PUSTAKA}

Pratono, A.H. (2020) Crowdfunding in digital humanities: some evidence from Indonesian social enterprises, Aslib Journal of Information Management 72(2), 287-303.

Solotke, T.M., Faria, Brussel, Nicole, Karim. H., Roy, S., Ross, S. J. (2020) Exploring crowdfunding campaigns for abortion service 1(102), 18-22.

Bagheri, Afsaneh, Chitsazan, H., Askhan, Ebrahim. (2019) Crowdfunding motivations : A focus on donors perspective (146), 218-232. 
